\title{
Rancang Bangun dan Pembuatan Mobil Listrik Bertenaga Solar Cell
}

\section{Rachmat Subagyo ${ }^{12}$, Abdul Ghofur ${ }^{12}$, Gunawan Rudi Cahyono ${ }^{1}$, Hajar Isworo ${ }^{1}$, M. Reynaldi Perdana Saputra ${ }^{1}$}

\author{
1 Program Studi Teknik Mesin, Universitas Lambung \\ Mangkurat
}

2Program Studi Pendidikan Profesi Insinyur, Universitas Lambung Mangkurat

rachmatsubagyo@ulm.ac.id

\section{Pendahuluan}

Mobil listrik adalah mobil yang digerakkan dengan motor DC menggunakan energi yang disimpan di dalam baterai. Penggunaan mobil listrik dirasa lebih efektif selain tidak menimbulkan polusi udara dan kontruksi mesin yang lebih sederhana dan sebagai sarana transportasi alternative (Adriana dkk, 2017).

Perkembangan penggunaan mobil listrik sudah mulai familier dimasyarakat salah satunya adalah digunakan pada wisata didaerah mangrove surabaya (Syaifulah dkk, 2012). Dimana mobil listrik Zeon sudah beroperasi untuk mengantar turis yang berwisata di daerah hutan bakau. Penggunaan mobil listrik ini merupakan salah satu pemanfaatan energi terbarukan yang diharapkan mengurangi penggunaan energi fosil yang kian menipis (Setiono, 2016).

Riset mobil listrik masih terus dilakukan karena masih ditemukannya adanya beberapa kelemahan. Kelemahan itu diantaranya adalah mengharuskan pemilik untuk mengisi baterai listrik di suatu tempat, karena belum tersedianya stasiun pembangkit listrik seperti halnya pom bensin bagi kendaraan konvensional.

Bukan hanya tentang ramah lingkungan atau tidaknya ternyata ukuran dan berat mobil juga sangat berpengaruh. Intinya, mobil berukuran lebih besar tentu membutuhkan tenaga baterai yang lebih banyak, dan semakin banyak tenaga yang mereka gunakan maka semakin banyak pula polusi yang ditimbulkan. Jika mobil listrik benar-benar ramah lingkungan seperti anggapan kebanyakan orang, maka mereka harus memastikan ukuran mobil tersebut lebih kecil.

Desain yang ringan, kokoh dan minimalis merupakan tujuan dari para peneliti. Untuk itu banyak
Tujuan proyek ini adalah untuk mengaplikasikan ilmu teknik mesin khususnya konversi energi dalam memanfaatkan energi matahari dengan menggunakan solar cell. Metode yang digunakan adalah eksperimental diawali dengan perancangan mobil listrik yang kemudian dilanjutkan proses pembuatannya. Proyek ini menghasilkan mobil listrik dengan data teknis sebagai berikut: kapasitas penumpang: 6 orang, kecepatan maksimum: $25 \mathrm{~km} / \mathrm{jam}$, jarak tempuh: $80 \mathrm{~km}$, kemampuan memanjat $\leq$ o,30, jarak pengereman $\leq 4 \mathrm{~m}$, Min. Turning Radius: $5 \mathrm{~m}$, Min Clearance: $150 \mathrm{~mm}$, waktu isi ulang 8-10 jam, Daya solar cell: 200 WP.

Kata kunci: teknik mesin, konversi energi, mobil listrik, solar cell

Diajukan: 30 November 2019

Direvisi: 14 Juni 2020

Diterima: 15 Juni 2020

Dipublikasikan online: 16 Juni 2020

peneliti menggunakkan bahan baja hollow yang memiliki struktur kuat dan ringan serta tahan terhadap panas.

Riset mobil listrik secara eksperimen memerlukan biaya yang cukup besar. Untuk mengatasi hal ini maka penelitian metode analisa numerik banyak berkembang (Setyono dan Gunawan, 2015), sebelum diaplikasikan pada desain yang sesungguhnya. Penelitian menggunakan metode numerik ini telah dilakukan dengan menggunakan ANSYS (Marzuki dkk, 2015), FEM (Nugroho, U., $d k k, 2018$ ), CATIA V5R19 (Taufik dkk, 2014), ANSYS / LS-DYNA (Wang dkk, 2017), model elemen hingga (Belingardi dan Obradovic, 2010) dan Autodesk Inventor (Siswanto dkk, 2019).

Riset ini dikembangkan untuk membuat sebuah kendaraan dengan menggunakan energi alternatif yang seefisien mungkin dengan emisi gas buang yang tidak mencemari lingkungan. Mobil ini direncanakan sebagai mobil operasional Rektorat Universitas Lambung mangkurat.

\section{Metode}

Riset ini melakukan analisa awal dengan metode simulasi pada pembebanan dan aerodinamis dengan menggunakan software Autodesk Inventor. Dengan analisa awal ini diharapkan hasil desain mobil listrik yang optimal dan handal, memenuhi syarat faktor keamanan yang tinggi.

\section{Hasil Kerja}

\section{Dimensi dan Chasis Mobil Listrik}

Dimensi dan chasis mobil listrik dirancang dengan ukuran yang aerodinamis, kokoh dan handal seperti ditunjukkan Gambar 1. Dengan kapasitas 6 penumpang, sumber tenaga dengan solar cell. Rangka dibuat dari

Cara mensitasi artikel ini:

Subagyo, R., Ghofur, A., Cahyono, G.R., Isworo., H., Saputra, M. R.D. (2020) Rancang Bangun dan Pembuatan Mobil Listrik Bertenaga Solar Cell. Buletin Profesi Insinyur 3(1) 001-010 


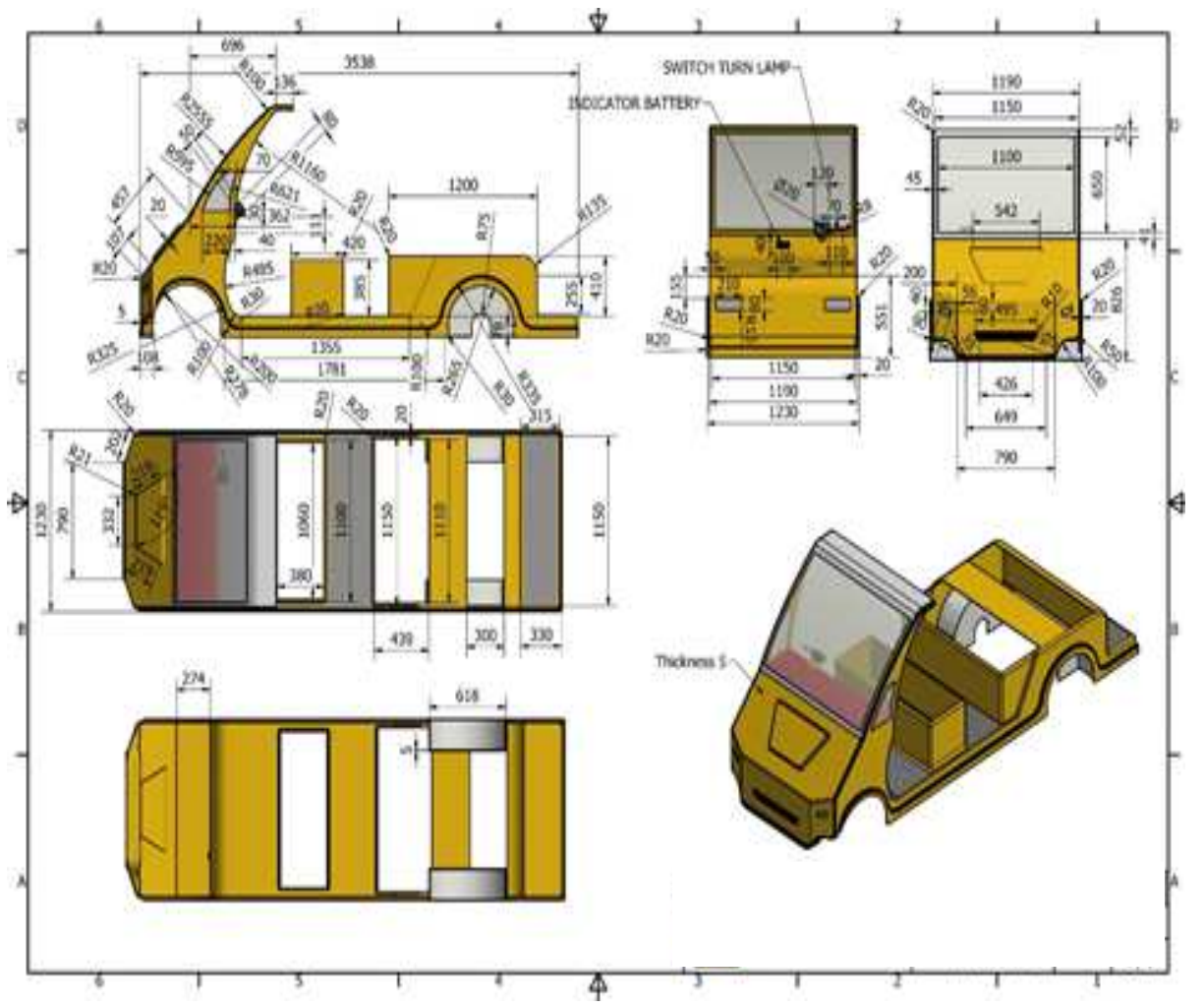

Gambar 1. Perancangan mobil listrik bertenaga solar cell

baja hollow, sedangkan bodi menggunakan Plat Galvanis yang dibentuk sedemikian rupa mengikuti bentuk mobil yang aerodinamis untuk mengurangi hambatan. Bahan kaca depan dengan mika tembus pandang sedangkan bodi dicat dengan warna kuning.

Dimensi mobil mengikuti referensi dari mobil listrik yang sudah ada sebagaimana ditunjukkan pada Tabel 1.

Tabel 1. Dimensi mobil listrik

\begin{tabular}{ll}
\hline Dimensi Kendaraan & Ukuran \\
\hline Tinggi kendaraan & $156 \mathrm{~cm}$ \\
Lebar kendaraan & $123 \mathrm{~cm}$ \\
Panjang kendaraan & $359 \mathrm{~cm}$ \\
Jarak antar roda & $123 \mathrm{~cm}$ \\
Jarak sumbu roda & $165 \mathrm{~cm}$ \\
Tinggi ruang kemudi & $826 \mathrm{~cm}$ \\
Lebar ruang kemudi & $115 \mathrm{~cm}$ \\
Jarak terendah & $30 \mathrm{~cm}$ \\
komponen kendaraan & \\
Berat total kendaraan & $250 \mathrm{~kg}$ \\
tanpa kemudi &
\end{tabular}

Bahan chasis adalah baja hollow $4 \times 7$ dengan penopang besi galvanis dan besi $L$ seperti ditunjukkan pada Gambar 2. Tujuan penggunaan baja hollow karena memiliki kekuatan yang baik. Baja ini tahan terhadap cuaca panas maupun dingin serta tidak mudah memuai. Kelebihan lain adalah mempunyai tampilan yang menarik dan pemasangan yang tergolong sangat mudah karena tidak perlu mempunyai keahlian khusus, serta tidak menghantarkan api.
Sifat-sifat mekanis baja hollow ditampilkan pada Tabel 2, hasil analisa dari nilai-nilai ini telah memenuhi syarat untuk desain chasis mobil listrik yang dirancang.

Tabel 2. Mechanical properties dari baja hollow bahan chasis

\begin{tabular}{lc}
\hline Mechanical properties & Nilai \\
\hline Mass Density & $7,850 \mathrm{gr} / \mathrm{cm}^{3}$ \\
Yield strenght & $207 \mathrm{MPa}$ \\
Ultimete tensile & $345 \mathrm{MPa}$ \\
strenght & \\
Young modulus & $210 \mathrm{GPa}$ \\
Poisson ratio & $0,3 \mathrm{ul}$ \\
\hline
\end{tabular}

\section{Analisa Koefisien drag pada bodi Mobil Listrik}

Analisis aerodinamis pada mobil listrik ini, menggunakan software Autodesk Flow Design.

Pengujian pertama membandingkan antara velocity dengan tekanan angkat, pada kondisi kecepatan mobil konstanta $80 \mathrm{~m} / \mathrm{s}$. Hasil analisa aerodinamika menunjukkan nilai koefisien gesek $\mathrm{Cd}$ : 0,64, gaya drag sebesar 49,152 $\mathrm{N}$ dan koefisien drag rata-rata sebesar 0,66 seperti ditunjukkan pada Gambar 3 .

\section{Analisis pembebanan pada chasis Mobil Listrik}

Analisa ini dimaksudkan untuk mengetahui kemampuan chasis dalam menopang beban pengemudi, penumpang, baterai, motor listrik serta beban secara keseluruhan yang ditanggung oleh chasis. Analisis yang dilakukan dengan autodesk inventor sebagai berikut:

\section{Analisis beban penumpang dan pengemudi}

Analisis ini menggunakan beban 6 penumpang dan pengemudi sebesar $350 \mathrm{Kg}$ seperti ditunjukkan pada 


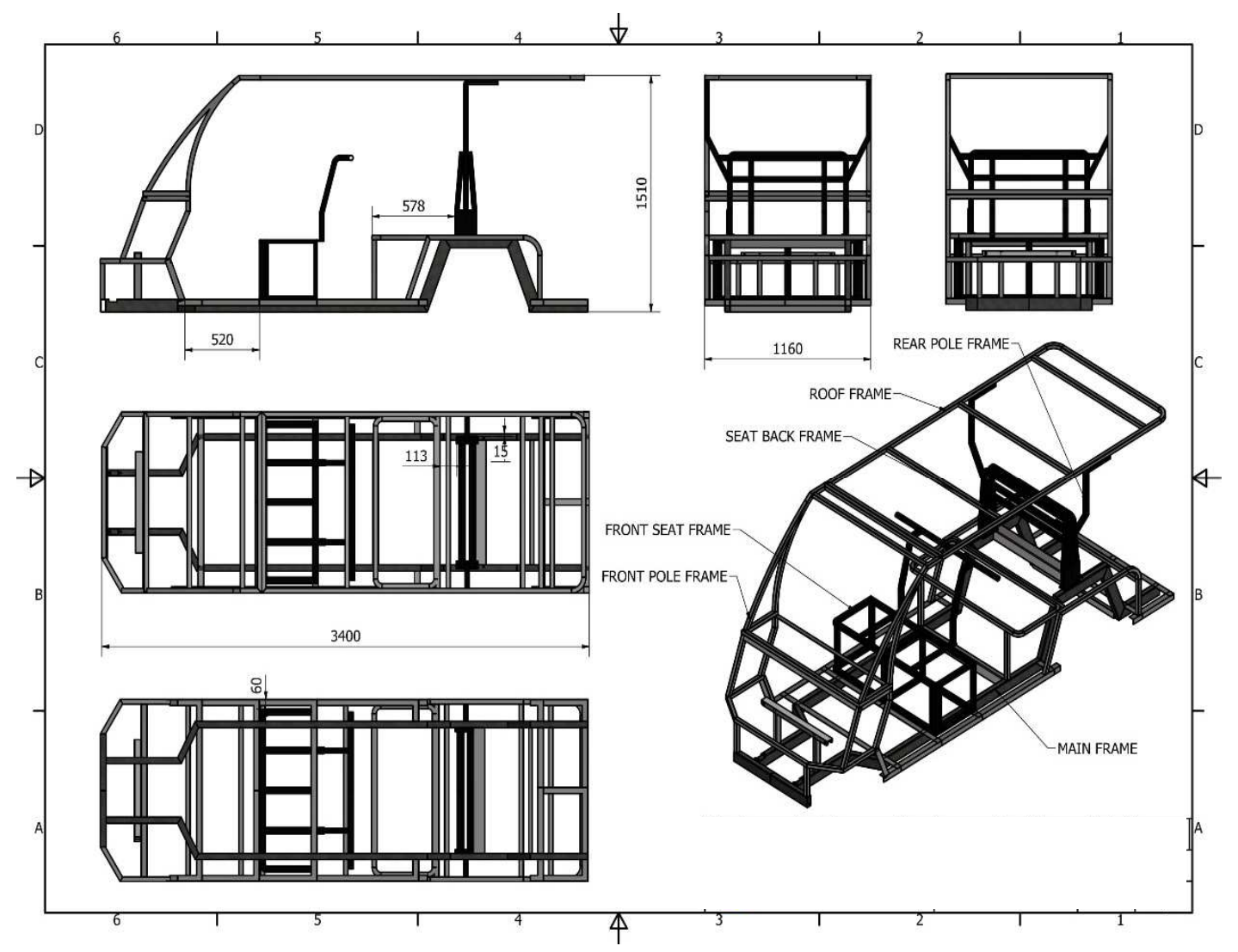

Gambar 2. Struktur chasis Mobil Listrik

Gambar 4. Pada gambar menunjukkan hasil analisis displacement dimana daerah yang berwarna biru menunjukkan displacement minimum sedangkan displacement maksimum ditunjukkan oleh daerah yang berwarna merah. Jika dilihat dari hasil analisis displacement maksimum terjadi disekitar pengemudi dimana jumlah beban cukup besar. Hasil pergeseran maksimum ditunjukkan dengan warna merah sebesar $34,77 \mathrm{~mm}$ dan tegangan minimum ditunjukkan dengan warna biru sebesar $0 \mathrm{~mm}$. Hasil analisa ini menunjukkan terjadinya perbedaan displacement yang cukup signifikan di bagian depan kendaraan. Untuk mengatasi hal ini diperlukan bahan dan proses penyambungan dengan las SMAW yang kuat, untuk menghindari terjadinya patahan pada bagian chasis tersebut. Hasil analisis beban driver pada chasis terlihat pada Tabel 3.

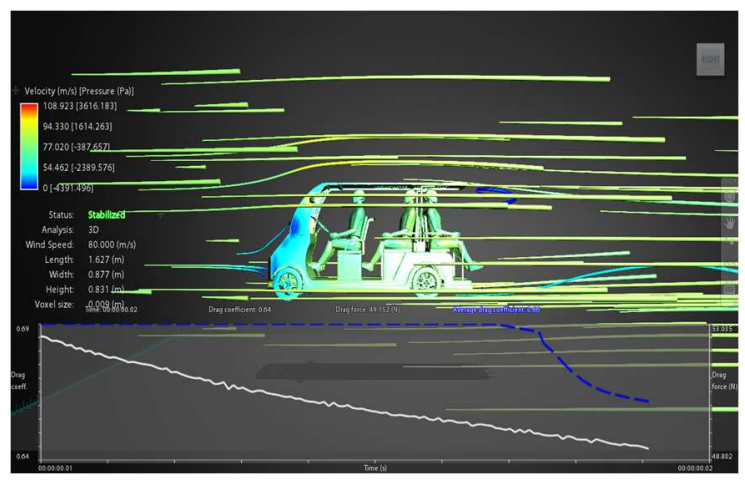

Gambar 3 Uji koefisien drag Mobil Listrik dengan autodesk inventor

\section{Analisis beban Baterai dan Motor listrik pada chasis}

Pada rangka ini dilakukan analisis beban mesin sebesar 150 N. Terlihat pada Gambar 5., menunjukkan daerah yang warna biru merupakan displacement minimum sedangkan displacement maksimum ditunjukan oleh daerah yang berwarna merah. Jika dilihat dari hasil analisis konsentrasi beban berada pada chasis disekitar rangka penyangga mesin menerima beban yang cukup besar. Hasil displacement maksimum ditunjukkan dengan warna merah sebesar 1,133 $\mathrm{Nm}$ dan tegangan minimum ditunjukkan dengan warna biru sebesar 0 . Daerah yang berwarna merah menunjukkan stress yang cukup tinggi. Untuk mengantisipasi hal itu maka dalam proses pengelasan harus diperhatikan pada titik-titik

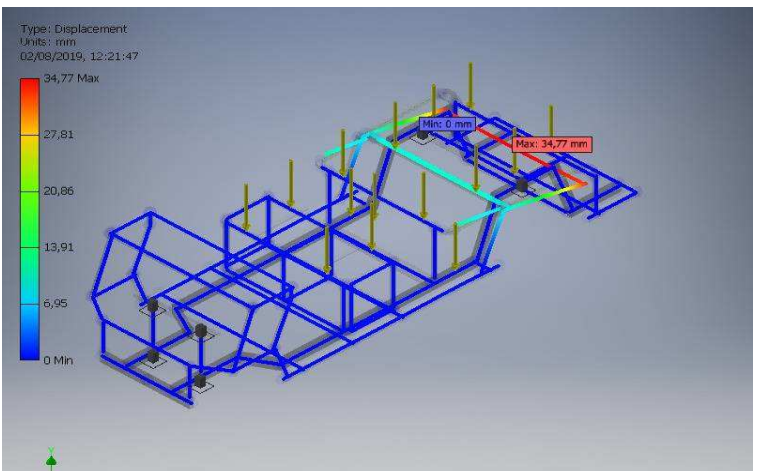

Gambar 4 Analisis beban penumpang dan driver menggunakan autodesk inventor 
sambungannya. Hasil analisis beban mesin pada chasis terlihat pada Tabel 4.

Tabel 3 Hasil analisis beban penumpang dan driver dengan Autodesk inventor

\begin{tabular}{|c|c|c|c|}
\hline Name & & Minimum & Maximum \\
\hline \multicolumn{2}{|l|}{ Displacement } & $0,000 \mathrm{~mm}$ & $34,777 \mathrm{~mm}$ \\
\hline \multirow[t]{3}{*}{ Forces } & $F x$ & $-2418,236 \mathrm{~N}$ & $2542,662 \mathrm{~N}$ \\
\hline & Fy & $-1986,849 \mathrm{~N}$ & $1461,682 \mathrm{~N}$ \\
\hline & $\mathrm{Fz}$ & $-2352,375 \mathrm{~N}$ & $1182,188 \mathrm{~N}$ \\
\hline \multirow[t]{3}{*}{ Moments } & $M x$ & $-348430,339 \mathrm{~N} \mathrm{~mm}$ & $306607,548 \mathrm{~N} \mathrm{~mm}$ \\
\hline & My & $-404579,759 \mathrm{~N} \mathrm{~mm}$ & $412337,734 \mathrm{~N} \mathrm{~mm}$ \\
\hline & $\mathrm{Mz}$ & $-92960,126 \mathrm{~N} \mathrm{~mm}$ & $88522,809 \mathrm{~N} \mathrm{~mm}$ \\
\hline \multirow{7}{*}{$\begin{array}{l}\text { Normal } \\
\text { Stresses }\end{array}$} & Smax & $-1,896 \mathrm{MPa}$ & $225,631 \mathrm{MPa}$ \\
\hline & Smin & $-252,533 \mathrm{MPa}$ & $1,236 \mathrm{MPa}$ \\
\hline & $\begin{array}{l}\text { Smax } \\
(\mathrm{Mx})\end{array}$ & 0,000 MPa & $94,791 \mathrm{MPa}$ \\
\hline & $\begin{array}{l}\text { Smin } \\
(\mathrm{Mx})\end{array}$ & $-252,902 \mathrm{MPa}$ & $0,000 \mathrm{MPa}$ \\
\hline & $\begin{array}{l}\text { Smax } \\
\text { (My) }\end{array}$ & $-0,000 \mathrm{MPa}$ & $227,230 \mathrm{MPa}$ \\
\hline & $\begin{array}{l}\text { Smin } \\
\text { (My) }\end{array}$ & $-227,230 \mathrm{MPa}$ & $0,000 \mathrm{MPa}$ \\
\hline & Saxial & $-5,283 \mathrm{MPa}$ & 4,603 MPa \\
\hline \multirow{2}{*}{$\begin{array}{l}\text { Shear } \\
\text { Stresses }\end{array}$} & $T x$ & $-17,805 \mathrm{MPa}$ & $11,667 \mathrm{MPa}$ \\
\hline & Ty & $-17,199 \mathrm{MPa}$ & $17,753 \mathrm{MPa}$ \\
\hline $\begin{array}{l}\text { Torsional } \\
\text { Stresses }\end{array}$ & $\mathrm{T}$ & $-20,470 \mathrm{MPa}$ & $20,194 \mathrm{MPa}$ \\
\hline
\end{tabular}

Tabel 4 Hasil analisis beban baterai dan motor listrik

\begin{tabular}{|c|c|c|c|}
\hline Name & & Minimum & Maximum \\
\hline Displaceme & & $0,000 \mathrm{~mm}$ & $1,133 \mathrm{~mm}$ \\
\hline Forces & $\mathrm{Fx}$ & $-662,185 \mathrm{~N}$ & $662,153 \mathrm{~N}$ \\
\hline & Fy & $-409,909 \mathrm{~N}$ & $288,652 \mathrm{~N}$ \\
\hline & $\mathrm{Fz}$ & $-497,725 \mathrm{~N}$ & $322,983 \mathrm{~N}$ \\
\hline Moments & $\mathrm{Mx}$ & $-69543,838 \mathrm{~N} \mathrm{~mm}$ & $31954,856 \mathrm{~N} \mathrm{~mm}$ \\
\hline & My & $-28899,056 \mathrm{~N} \mathrm{~mm}$ & $28051,187 \mathrm{~N} \mathrm{~mm}$ \\
\hline & $\mathrm{Mz}$ & $-22816,346 \mathrm{~N} \mathrm{~mm}$ & $22816,038 \mathrm{~N} \mathrm{~mm}$ \\
\hline Normal & Smax & $-0,403 \mathrm{MPa}$ & $8,789 \mathrm{MPa}$ \\
\hline Stresses & Smin & $-9,813 \mathrm{MPa}$ & $0,473 \mathrm{MPa}$ \\
\hline & $\begin{array}{l}\text { Smax } \\
(\mathrm{Mx})\end{array}$ & $0,000 \mathrm{MPa}$ & $5,324 \mathrm{MPa}$ \\
\hline & $\begin{array}{l}\text { Smin } \\
(M x)\end{array}$ & $-8,813 \mathrm{MPa}$ & $0,000 \mathrm{MPa}$ \\
\hline & $\begin{array}{l}\text { Smax } \\
\text { (My) }\end{array}$ & $-0,000 \mathrm{MPa}$ & 8,895 MPa \\
\hline & $\begin{array}{l}\text { Smin } \\
\text { (My) }\end{array}$ & $-8,895 \mathrm{MPa}$ & $0,000 \mathrm{MPa}$ \\
\hline & Saxial & $-0,489 \mathrm{MPa}$ & 0,753 MPa \\
\hline Shear & $T x$ & $-3,195 \mathrm{MPa}$ & 3,195 MPa \\
\hline Stresses & Ty & $-0,989 \mathrm{MPa}$ & 1,081 MPa \\
\hline $\begin{array}{l}\text { Torsional } \\
\text { Stresses } \\
\end{array}$ & T & $-0,765 \mathrm{MPa}$ & $0,764 \mathrm{MPa}$ \\
\hline
\end{tabular}

\section{Analisis beban keseluruhan pada Chasis}

Pada frame ini dilakukan analisis beban keseluruhan pada mobil listrik. Analisis stress yang terjadi akibat beban driver, passenger, baterai, motor listrik, dan sistem penggerak yang terdapat pada rangka. Seperti terlihat pada Gambar 6, daerah yang warna biru merupakan displacement minimum sedangkan displacement maksimum ditunjukan oleh bidang berwarna merah. Hasil displacement maksimum ditunjukkan dengan warna merah sebesar 34,767 Nm dan displacement minimum ditunjukkan dengan warna biru sebesar 0 . Perbedaan tegangan cukup besar hampir sama dengan beban penumpang dan pengemudi. Proses pembuatan chasis perlu memperhatikan daerahdaerah yang mempunya tegangan cukup tinggi. Hasil analisis beban keseluruhan pada chasis terlihat pada Tabel 5.

\section{Rancangan Steering System}

Rancangan Steering system ditampilkan pada Gambar 7. Ketika steering wheel diputar oleh pengemudi, maka steering shaft akan berputar sehingga pinion pun juga ikut berputar. Putaran pada pinion ini membuat rack bergerak ke samping (baik ke kanan atau ke kiri) yang selanjutnya gerakan menyamping ini diteruskan menuju tie rod kemudian ke knuckle arm pada rodaroda depan sehingga salah satu sisi roda akan terdorong, dan sisi lainnya akan tertarik. Hal ini menyebabkan roda berbelok atau berputar ke arah yang sama.

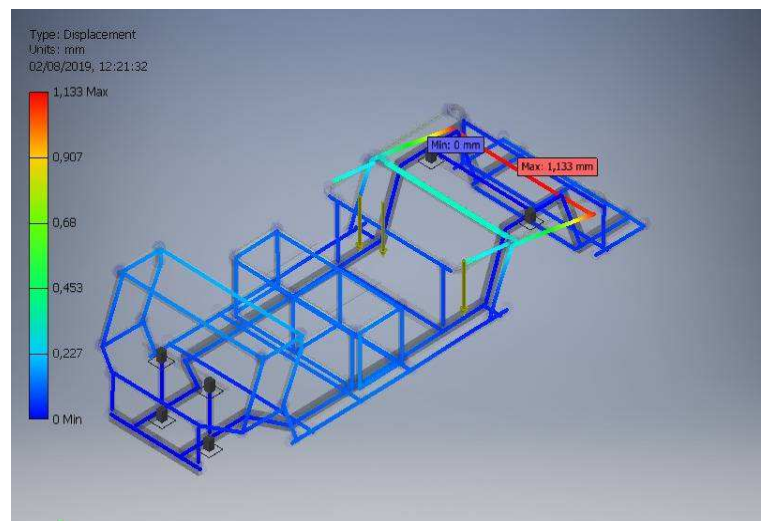

Gambar 5. Analisis beban baterai dan Motor listrik menggunakan autodesk inventor

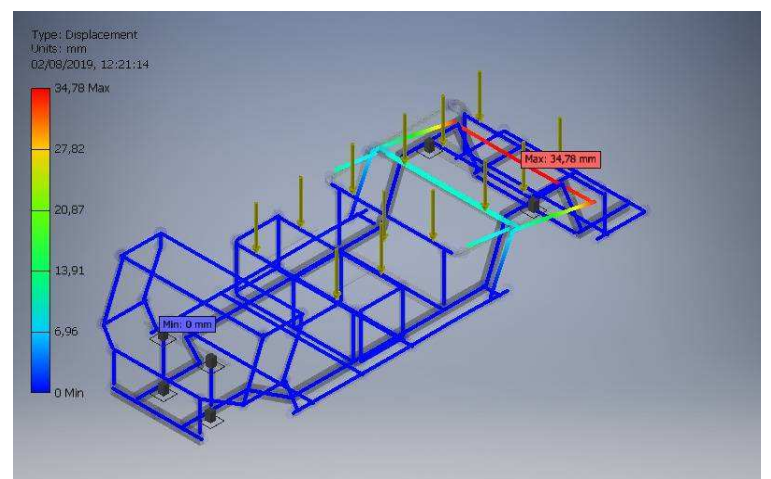

Gambar 6 Analisa pembebanan keseluruhan pada chasis Mobil Listrik 


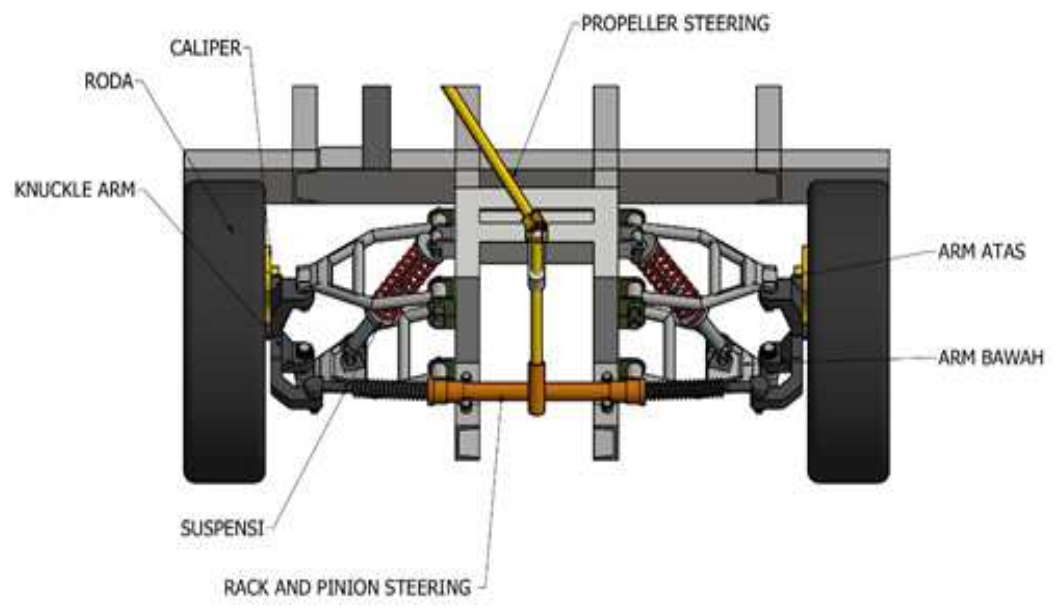

Gambar 7 Rancangan sistem steering

\begin{tabular}{|c|c|c|c|}
\hline \multicolumn{2}{|c|}{$\begin{array}{l}\text { Analisis } \\
\text { pembebanan }\end{array}$} & Minimum & Maximum \\
\hline \multicolumn{2}{|c|}{ Displacement } & $0,000 \mathrm{~mm}$ & $34,767 \mathrm{~mm}$ \\
\hline \multirow[t]{3}{*}{ Forces } & $F x$ & $-2650,175 \mathrm{~N}$ & $2774,585 \mathrm{~N}$ \\
\hline & Fy & $-2157,472 \mathrm{~N}$ & $1462,474 \mathrm{~N}$ \\
\hline & $\mathrm{Fz}$ & $-2559,403 \mathrm{~N}$ & $1279,833 \mathrm{~N}$ \\
\hline \multirow[t]{3}{*}{ Moments } & $M x$ & $-377855,2 \mathrm{Nmm}$ & $306547,6 \mathrm{Nmm}$ \\
\hline & My & $-404579,8 \mathrm{Nmm}$ & $412337,7 \mathrm{Nmm}$ \\
\hline & $\mathrm{Mz}$ & $-93078,3 \mathrm{Nmm}$ & $88640,9 \mathrm{Nmm}$ \\
\hline \multirow{7}{*}{$\begin{array}{l}\text { Normal } \\
\text { Stresses }\end{array}$} & Smax & $-1,880 \mathrm{MPa}$ & $225,633 \mathrm{MPa}$ \\
\hline & Smin & $-252,470 \mathrm{MPa}$ & $1,207 \mathrm{MPa}$ \\
\hline & $\begin{array}{l}\text { Smax } \\
(\mathrm{Mx})\end{array}$ & $0,000 \mathrm{MPa}$ & $94,773 \mathrm{MPa}$ \\
\hline & $\begin{array}{l}\text { Smin } \\
(M x)\end{array}$ & $-252,853 \mathrm{MPa}$ & $0,000 \mathrm{MPa}$ \\
\hline & $\begin{array}{l}\text { Smax } \\
\text { (My) }\end{array}$ & $-0,000 \mathrm{MPa}$ & $227,230 \mathrm{MPa}$ \\
\hline & $\begin{array}{l}\text { Smin } \\
(\mathrm{My})\end{array}$ & $-227,230 \mathrm{MPa}$ & $0,000 \mathrm{MPa}$ \\
\hline & Saxial & $-5,296 \mathrm{MPa}$ & $4,614 \mathrm{MPa}$ \\
\hline \multirow{2}{*}{$\begin{array}{l}\text { Shear } \\
\text { Stresses }\end{array}$} & $T x$ & $-17,814 \mathrm{MPa}$ & $12,786 \mathrm{MPa}$ \\
\hline & Ty & $-17,209 \mathrm{MPa}$ & $17,763 \mathrm{MPa}$ \\
\hline $\begin{array}{l}\text { Torsional } \\
\text { Stresses }\end{array}$ & $\mathrm{T}$ & $-20,506 \mathrm{MPa}$ & $20,231 \mathrm{MPa}$ \\
\hline
\end{tabular}

\section{Perhitungan Daya penggerak Mobil Listrik}

Pada perancangan ini menggunakkan tegangan Aki: 48 Volt, arus yang dihasilkan motor listrik: 73,82 Ampere dan putaran dari motor adalah $157 \mathrm{rpm}$. Sehingga daya yang mampu dibangkitkan oleh mobil listrik ini adalah:

$$
\begin{aligned}
\mathrm{P} & =\mathrm{Ia} . \mathrm{Ea} \\
& =48 \mathrm{v} .73,82 \mathrm{~A} \\
& =3.548,16 \text { watt }(3,54816 \mathrm{Kw})
\end{aligned}
$$

Kecepatan sudut dari motor adalah:

$$
\begin{aligned}
\omega & =\frac{2 \pi \cdot N}{60} \\
& =\frac{2.3,14.1500}{60} \\
& =157 \mathrm{rpm}
\end{aligned}
$$

Sehingga torsi motor adalah:

$$
T=\frac{p}{\omega}
$$

$$
\begin{aligned}
& =\frac{3.548,16}{157} \\
& =22,59 \mathrm{Nm}
\end{aligned}
$$

Torsi yang diperlukan untuk menggerakan mobil listrik:

berat mobil total: $530 \mathrm{~kg}$, diameter ban: $0,50 \mathrm{~m}$, sehingga kecepatan linearnya adalah:

Kecepatan linier $=r . \omega$

$$
\begin{aligned}
& =0,3 \cdot 157 \\
& =78,5 \mathrm{~m} / \mathrm{s}
\end{aligned}
$$

Torsi minimal yang digunakkan untuk menggerakan mobil:

$$
\begin{aligned}
& \mathrm{T}=\frac{530}{78,5}=6,75 \mathrm{Nm} \\
& <\text { Torsi motor listrik }(22,59 \mathrm{Nm})
\end{aligned}
$$

Perhitungan daya mobil listrik:

$$
\begin{aligned}
P & =\frac{\tau \cdot N \cdot 2 \cdot \pi}{60} \\
& =\frac{6,75 \cdot 1500 \cdot 2 \cdot 3,14}{60} \\
& =1.059,75 \text { watt }<3,5 \mathrm{kw} \text { (daya motor listrik) }
\end{aligned}
$$

\section{Rancangan Breaking}

Konstruksi rem tromol memiliki dua buah kampas rem yang terletak dibagian dalam seperti ditunjukkan Gambar 8. Dibagian luar kampas rem terdapat komponen berbentuk mangkuk yang kita kenal sebagai tromol rem. Arah gerakan rem tromol itu saling menjauhi, artinya saat rem ditekan maka dua buah kampas rem akan bergerak ke arah luar (saling menjauhi). Gerakan tersebut akan membuat kampas rem menekan permukaan dalam tromol rem. Sehingga terjadilah gesekan yang akan menghentikan putaran tromol dan roda.

Alasan penggunaan rem tromol pada mobil listrik ini, yaitu: Lebih awet karena memiliki kampas rem yang lebar. Permukaan kampas rem lebar membuat daya pengereman cukup kuat serta lembut, sehingga cocok dipakai pada mobil berbobot besar lebih bersih (aman dari kotoran luar) karena sistem rem ini bersifat tertutup. 


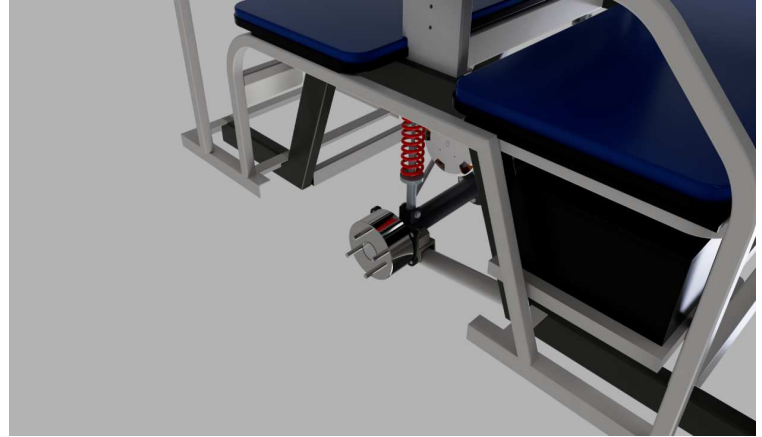

Gambar 8 Rancangan sistem breaking

\section{Rancangan Motor Penggerak}

Penggerak roda belakang Gambar 9, menggunakan Motor DC 3.300 Watt yang memiliki torsi yang besar dan perawatannya yang sangat mudah. Penggunaan gardan dengan rasio perbandingan 1:15 yang memiliki kecepatan maksimal $20 \mathrm{~km} / \mathrm{jam}$. Dengan torsi diawal yang melimpah dengan meminimalkan suplai daya dari baterai yang dikonversi menjadi energi mekanik ke gardan agar konsumsi daya menjadi sedikit/hemat. Karena konsep awal dari mobil listrik ini adalah mengejar efisiensi dari konsumsi daya, sehingga tidak terlalu mengutamakan kecepatan, melainkan efisiensinya.

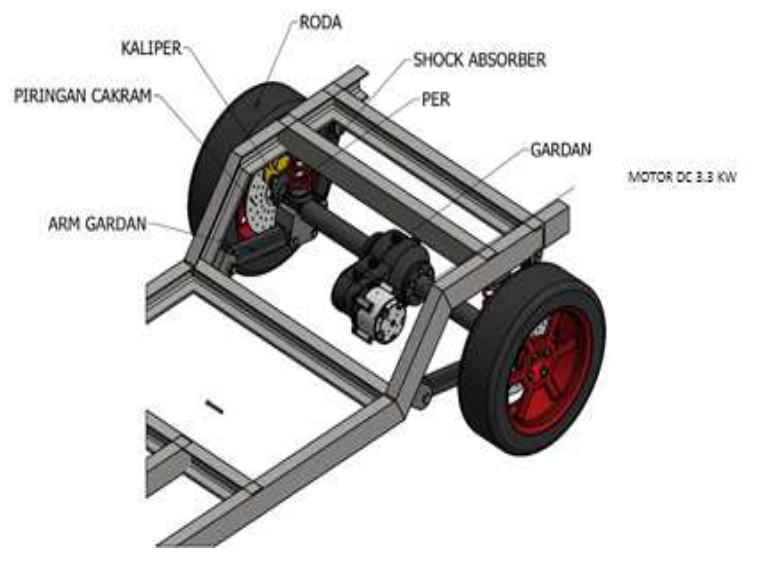

Gambar 9 Rancangan motor penggerak

\section{Rancangan Safety}

Pada rancangan safety digunakan besi hollow untuk keamanan pengendara, sehingga penumpang tidak akan terjatuh keluar dari mobil. Konstruksi dari safety di pasang pada kursi penumpang sebelah kanan dan kiri dan kursi driver seperti ditunjukkan pada Gambar 10. Kecepatan dari mobil ini juga tidak terlalu cepat, karena faktor keamanan, kenyamanan dan keindahan menjadi alasan utama dari pembuatan mobil tersebut.

\section{Diagram Kelistrikan}

Bagian-bagian penting dari diagram kelistrikan ditunjukan pada Gambar 11. Fungsi dari masing-masing komponen adalah: Potentiometer berfungsi sebagai untuk mengendalikan peranti elektronik seperti pengendali suara pada penguat, Controller Electric untuk mengatur torsi yang dihasilkan oleh mobil kendaraan listrik, Electric Motor untuk mengubah energi listrik menjadi energi mekanik.

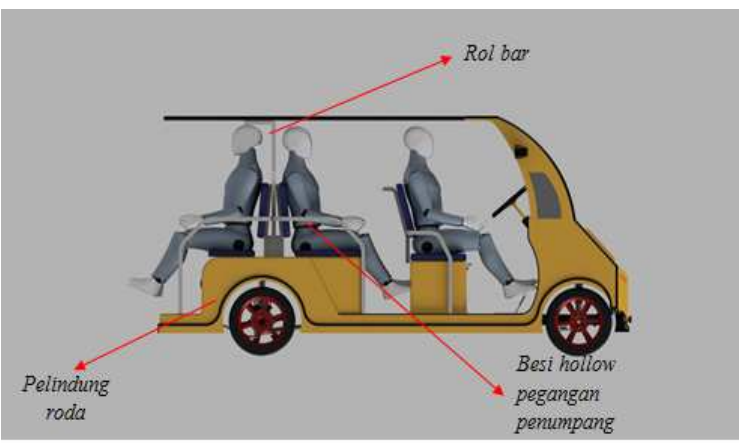

Gambar 10 Rancangan keamanan mobil

Bagian komponen yang lain adalah Charger Port untuk memudahkan menyambungkan arus kelistrikan, Solenoid sebagai komponen yang mengalirkan listrik dengan menggunakan arus yang besar tetapi dengan kendali listrik yang memiliki arus relatif kecil, Battery berfungsi untuk menyimpan arus listrik yang dihasilkan oleh solar cell, Key Switch berfungsi untuk menghidupkan mobil, Battery Indicator perangkat yang memberikan informasi tentang baterai, Forward Reverse Switch berfungsi untuk membalikan arah putaran, Solar cell berfungsi untuk Mengkonversi energi panas dari radiasi matahari menjadi energi listrik dan Controller Solar Cell Untuk mengatur arus yang masuk serta mengkontrol berapa daya yang diserap dan dikonsumsi oleh mobil tersebut.

Gambar 12 menunjukkan diagram wiring solar cell, dimana hasil energi matahari diubah menjadi energi listrik kemudian disimpan pada baterai yang penggunaanya di atur oleh Controller Solar Cell. Solar cell ini dipasang di atap mobil berfungsi untuk menangkap energi matahari sekaligus sebagai pelindung.

\section{Produksi Mobil Listrik}

Tahapan dari produksi mobil listrik Gambar 13 dimulai dengan, pembentukan team pelaksana proses produksi, analisis kebutuhan, spesifikasi project, proses produksi meliputi: pembuatan rangka, perakitan bodi dan pembuatan part. Setelah selesai proses produksi dilanjutkan dengan perakitan (assembly) dan dilakukan proses uji coba.

\section{Proses pembuatan rangka utama:}

Pembuatan rangka utama dimulai dengan menyiapkan bahan rangka baja Hollow ukuran $4 \times 6$, dengan ketebalan $3 \mathrm{~mm}$ dan besi siku ukuran $4 \times 4$, kemudian dilakukan penyambungan dengan menggunakan las SMAW. Proses pengelasan pada rangka utama di tunjukkan pada Gambar 14a, proses pengelasan pada kursi kemudi depan 14b, pengelasan pada kursi penumpang 14.c, dan pemberian cat dasar (epoxy) terhadap rangka untuk menjaga korosi 14.d. 


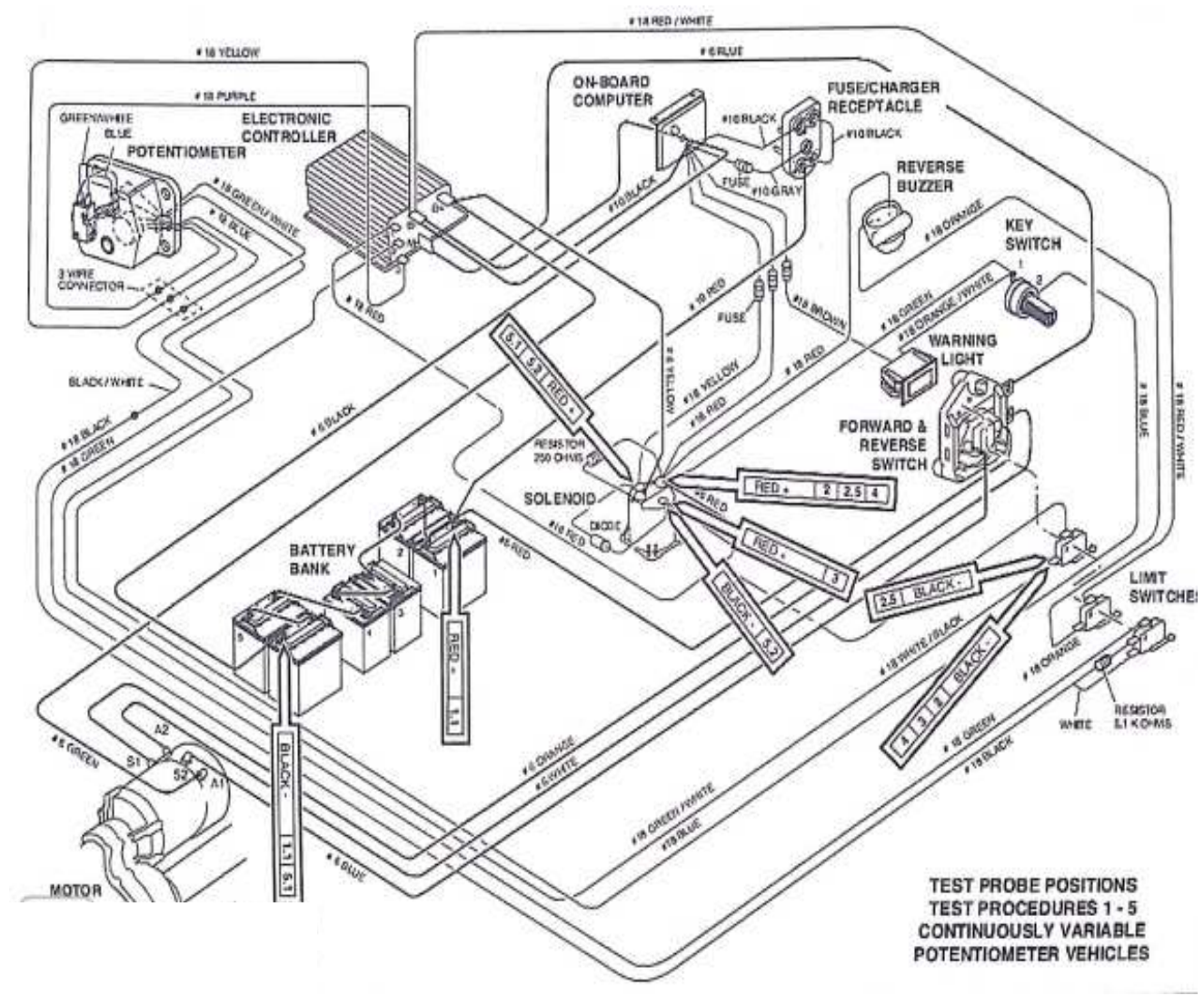

Gambar 11 Diagram kelistrikan penggerak

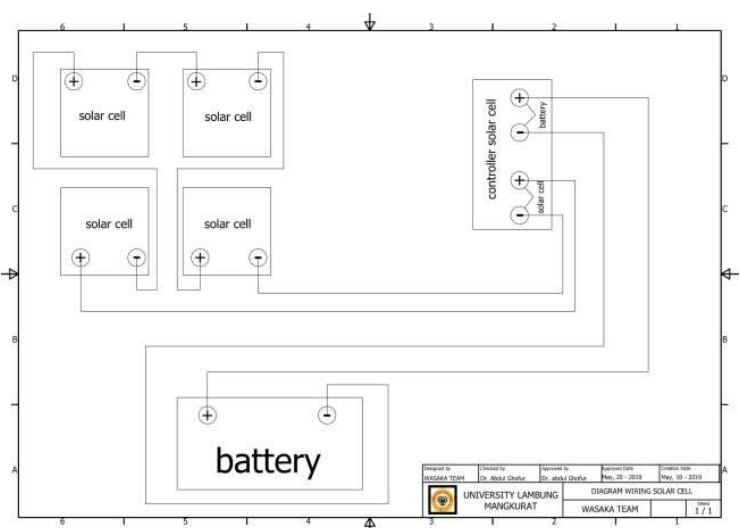

Gambar 12 Rancangan diagram kelistrikan

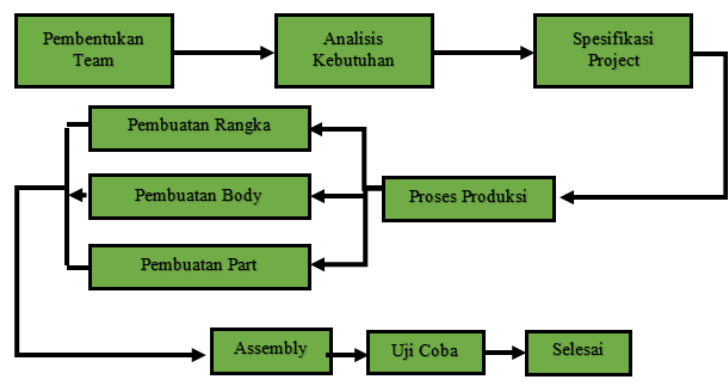

Gambar 13 Diagram alir tahapan produksi Mobil listrik

\section{Proses pembuatan bodi}

Proses pembuatan bodi terlihat pada Gambar 15. Proses ini meliputi, pemasangan bodi pada rangka 15.a, pendempulan dan pengecatan dasar 15.b, pengamplasan/penggosokan 15.c, dan penghalusan bodi kendaraan 15.d, mencetak sandaran kursi dengan fiber glass 15.e.

Dilanjutkan dengan 15.e, pencetakan sandaran kursi dengan fiber glass, 15.f, pembuatan rangka atap (tempat dudukan solar cell), 15.g dan 15.h, memvernis pada seluruh permukaan bodi. Proses ini dilakukan secara bertahap untuk mendapatkan hasil yang memuaskan.

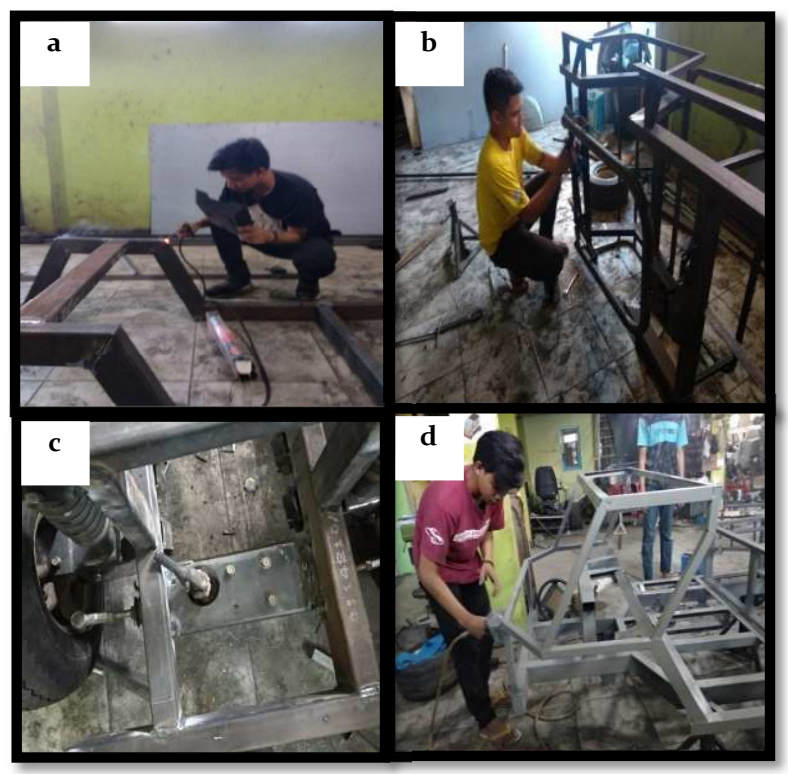

Gambar 14 Proses pembuatan rangka utama 


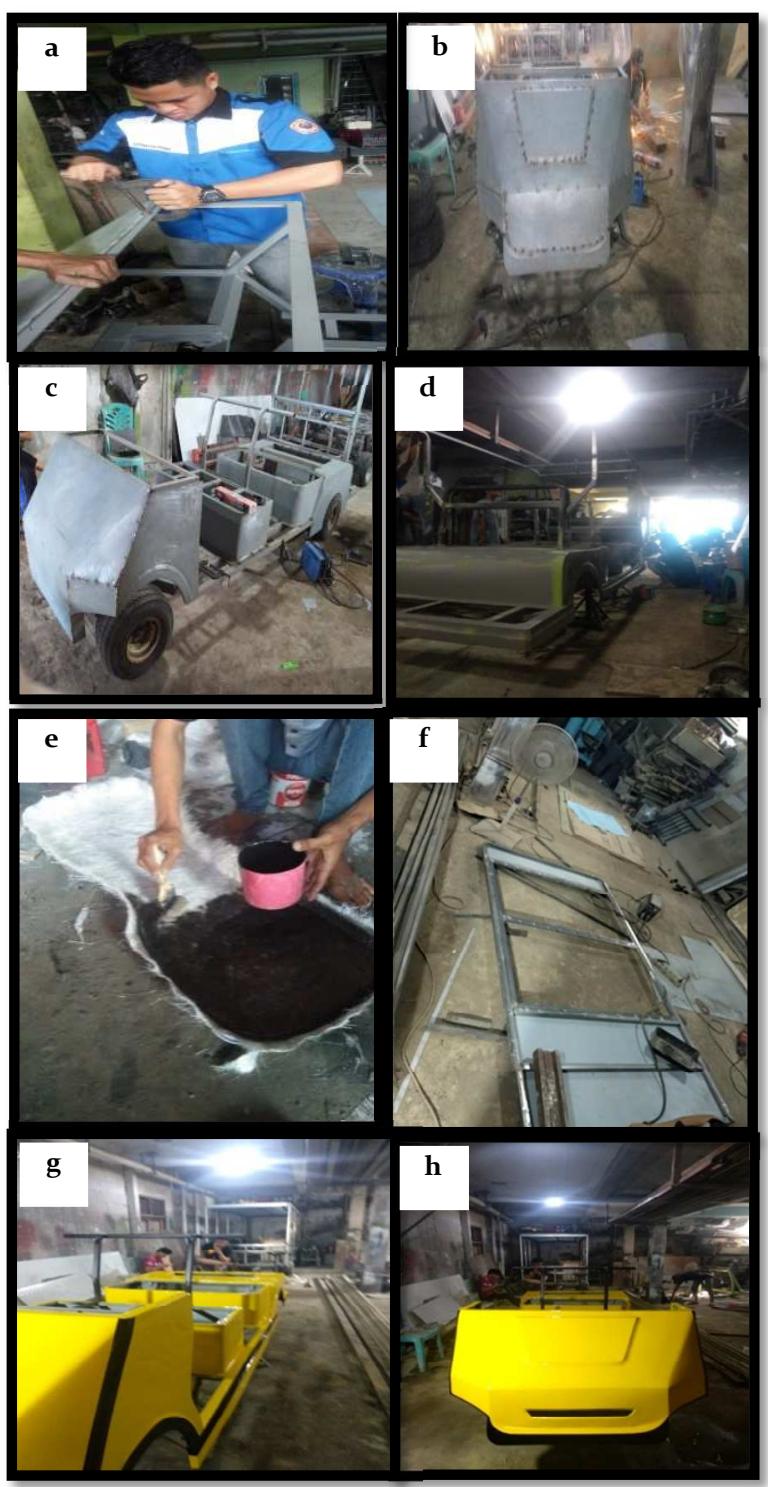

Gambar 15 Proses pembuatan bodi kendaraan

\section{Proses pemasangan part}

Proses pemasangan part (Gambar 16) dimulai dengan pemasangan sistem penggerak belakang (gardan) 16.a/16.b, memasang sistem Steering 16.c, memasang Shock Absorber 16.d.

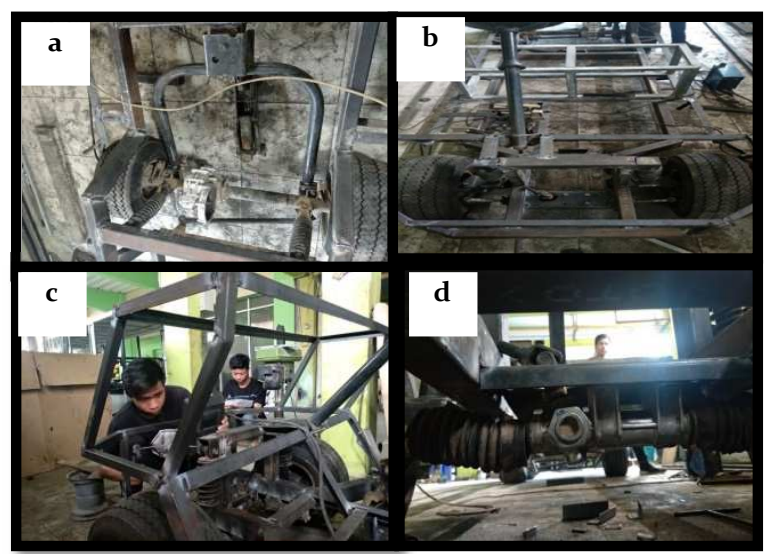

Gambar 16 Proses pemasangan part pada rangka

\section{Proses Assembly}

Proses assembly terlihat pada Gambar 17, meliputi: wiring solar cell 17.a, pemasangan 17.b/ 17.c kursi, pemasangan sensor indikator baterai 17.d.

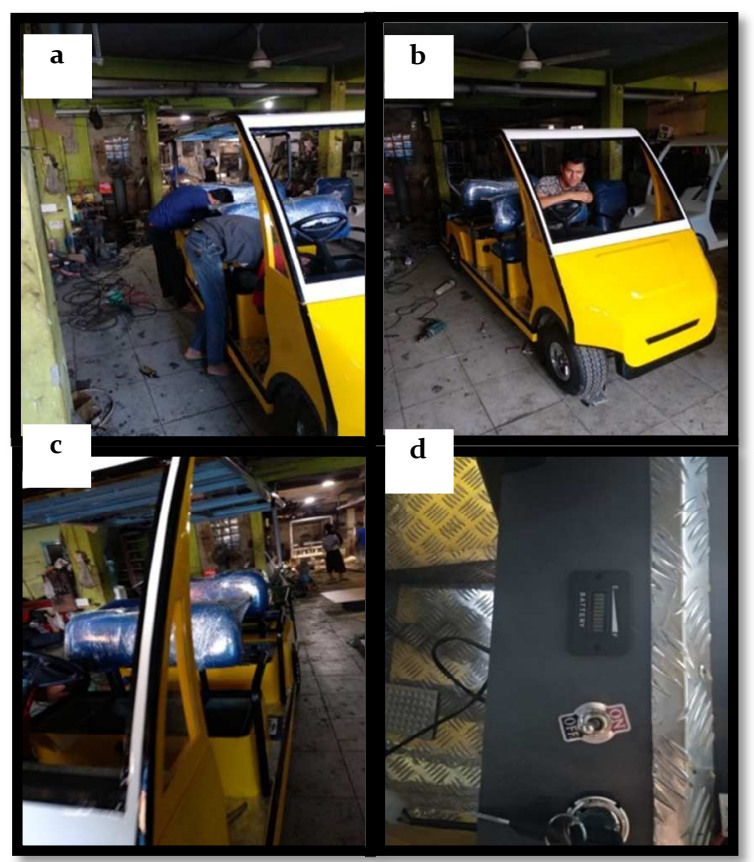

Gambar 17 Proses assembly pada kendaraan

Pada Tabel 6, ditampilkan data teknis dari Solar cell yang digunakan pada motor listrik sebagai sumber tenaganya.

\begin{tabular}{lll}
\multicolumn{2}{l}{ Tabel 6 Data teknik Solar cell } \\
\hline No. & Data & Kapasitas \\
\hline 1. & Max. Power (Pmax) & $200 \mathrm{~W}$ \\
2. & Max. Power Voltage (Vmp) & $17.5 \mathrm{~V}$ \\
3. & Max. Power Current (Imp) & $5.71 \mathrm{~A}$ \\
4. & Open Circuit Voltage (Voc) & $21 \mathrm{~V}$ \\
5. & Short Circuit Current (Isc) & $6.4 \mathrm{~A}$ \\
6. & Nominal Operating Cell & $45 \pm 2^{\circ} \mathrm{C}$ \\
& Temp (NOCT) & \\
7. & Max. System Voltage & $1000 \mathrm{~V}$ \\
8. & Max. Series Fuse & $16 \mathrm{~A}$ \\
9. & Weight & $7.55 \mathrm{Kg}$ \\
10. & Dimension (mm) & $1085 \times 675 \times 25$ \\
\hline
\end{tabular}

\section{Uji Coba}

Keberhasilan dalam pembuatan mobil listrik didukukung oleh pemilihan komponen-komponen terbaik yang mendukung. Komponen-komponen mobil yang digunakan ditampilkan pada Tabel 6 .

\begin{tabular}{lll}
\multicolumn{2}{l}{ Tabel 6 Spesifikasi komponen-komponen Mobil Listrik } \\
\hline No. & $\begin{array}{l}\text { Komponen } \\
\text { mesin }\end{array}$ & Data teknis \\
\hline 1. & Motor & $\begin{array}{l}\text { Motor DC 48 V DC 3.3 KW / 250 } \\
\text { A, bertenaga, performa traksi } \\
\text { yang superior, kebisingan } \\
\text { rendah, kapasitas overload, }\end{array}$ \\
\hline
\end{tabular}




\begin{tabular}{|c|c|c|}
\hline & & $\begin{array}{lll}\text { umur } & \text { pemakaian } & \text { yang } \\
\text { panjang. } & & \end{array}$ \\
\hline 2. & Kontroller & $\begin{array}{l}\text { Automatic Controller dengan } \\
\text { Potensiometer }\end{array}$ \\
\hline 3. & Baterai & $\begin{array}{l}\text { Baterai Trojan perawatan } \\
\text { bebas } 8 \mathrm{~V} / 165 \mathrm{Ah} * 6 \mathrm{pcs}\end{array}$ \\
\hline 4. & Atap & $\begin{array}{l}\text { Lapisan Fiber dengan rangka } \\
\text { dari Hollow }\end{array}$ \\
\hline 5. & Body & $\begin{array}{l}\text { Plat Galvanis yang dibentuk } \\
\text { sedemikian rupa }\end{array}$ \\
\hline 6. & Kaca Depan & Kaca Mika \\
\hline 7. & Tempat Duduk & $\begin{array}{l}\text { Kulit Sintetis dengan busa yang } \\
\text { empuk dan base chair dari } \\
\text { fiber }\end{array}$ \\
\hline 8. & Kaca Spion & $\begin{array}{l}3 \text { buah, spion eksterior } \\
\text { manual, } \\
\text { menyeluruh tentang kondisi } \\
\text { jalan }\end{array}$ \\
\hline 9. & Pengecatan & $\begin{array}{l}\text { Pengecatan dengan warna } \\
\text { premium yang ditembakan } \\
\text { oleh kompressor }\end{array}$ \\
\hline 10. & Ban & $18 \times 8.50$ Ring 8 \\
\hline 11. & Frame & Rangka Hollow \\
\hline 12. & Charger & $\begin{array}{l}\text { Pulsa efisiensi tinggi otomatis, } \\
\text { Output: } 48 \mathrm{~V} / 18 \mathrm{~A} \text {, Input AC } \\
220 \mathrm{~V} / 5 \mathrm{HZ}\end{array}$ \\
\hline 13. & $\begin{array}{l}\text { Kapasitas } \\
\text { Penumpang }\end{array}$ & 6 Penumpang \\
\hline 14. & $\begin{array}{l}\text { Kecepatan } \\
\text { Maksimum }\end{array}$ & $25 \mathrm{~km} / \mathrm{jam}$ \\
\hline 15. & Jarak Tempuh & $80 \mathrm{~km}$ \\
\hline 16. & $\begin{array}{l}\text { Kemampuan } \\
\text { Memanjat } \\
\text { (loaded) }\end{array}$ & $\leq 0,30$ \\
\hline 17. & $\begin{array}{l}\text { Jarak } \\
\text { Pengereman }\end{array}$ & $\leq 4 \mathrm{~m}$ \\
\hline 18. & $\begin{array}{l}\text { Min. Turning } \\
\text { Radius }\end{array}$ & $5 \mathrm{~m}$ \\
\hline 19. & Min Clearance & $150 \mathrm{~mm}$ \\
\hline 20. & Waktu Isi Ulang & $8 \sim 10$ hour \\
\hline 21. & Solar Cell & $200 \mathrm{WP}$ \\
\hline
\end{tabular}

Gambar 18 adalah hasil mobil listrik yang sudah selesai diproduksi. Warna bodi kuning yang sudah dilengkapi dengan dudukan sebanyak 6 penumpang dilengkapi dengan kursi pengemudi. Bagian atas dilengkapi dengan atap solar cell.

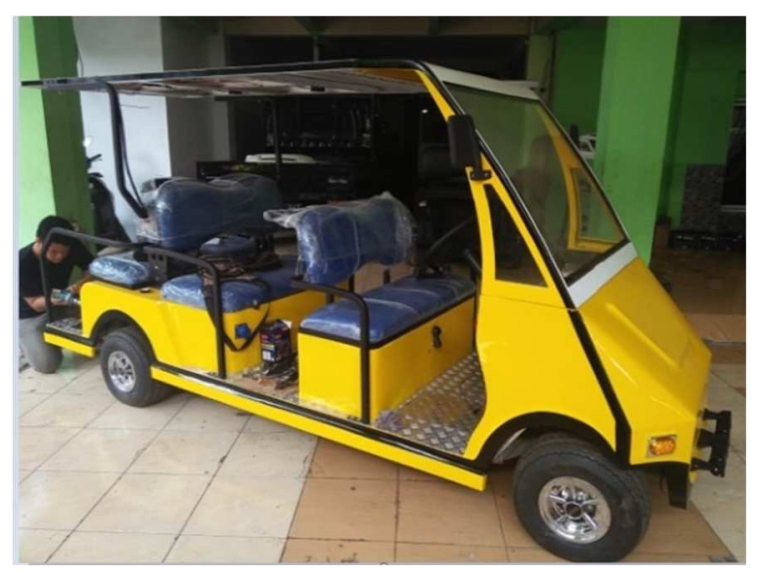

Gambar 18 Hasil pembuatan mobil listrik bertenaga Solar cell

Keunggulan-keunggulan yang dimiliki oleh mobil listrik hasil rancangan ditampilkan pada Tabel 7.
Tabel 7 Keunggulan Teknis Mobil listrik

\begin{tabular}{|c|c|c|}
\hline No. & Komponen & keunggulan \\
\hline 1. & Pengontrol & $\begin{array}{l}\text { Kontrol elektronik pendukung khusus dan } \\
\text { sistem pengubah kecepatan tanpa } \\
\text { stepless, pengendali memiliki suhu yang } \\
\text { lebih rendah, arus kontrol yang lebih } \\
\text { besar, motor yang lebih stabil, lebih } \\
\text { bertenaga, dan memainkan efisiensi } \\
\text { motor yang paling tinggi. }\end{array}$ \\
\hline 2. & Baterai & $\begin{array}{l}\text { Kapasitas besar baterai daya dalam siklus, } \\
\text { keamanan yang baik, umur panjang, masa } \\
\text { kerja yang tinggi. }\end{array}$ \\
\hline 3. & Atap & $\begin{array}{l}\text { Langit-langit baja khusus baja golf, tahan } \\
\text { air dengan tambahan Panel Surya untuk } \\
\text { penggunaan energi yang Re-useable yang } \\
\text { berlangsung secara continu. }\end{array}$ \\
\hline 4. & Tubuh & $\begin{array}{l}\text { Kaca serat berefek tinggi, bodinya super } \\
\text { kuat, tahan korosi, umur panjang bahan } \\
\text { plastik diperkuat serat gelas otomotif, } \\
\text { cantik dan tahan lama, ringan dan } \\
\text { kelebihan unik lainnya. }\end{array}$ \\
\hline 5. & Kaca Depan & $\begin{array}{l}\text { See-through Laminated glass, kaca depan } \\
\text { golf spesial. }\end{array}$ \\
\hline 6. & Motor & $\begin{array}{l}\text { Performa traksi yang superior, kebisingan } \\
\text { rendah, kapasitas overload, umur } \\
\text { pemakaian yang panjang dengan } \\
\text { perawatan yang mudah. }\end{array}$ \\
\hline 7. & Kursi & $\begin{array}{l}\text { Dua baris ke arah depan, kain kulit imitasi } \\
+ \text { PU rebound tinggi, dengan pegangan } \\
\text { tangan, dan tahan air serta tampilan yang } \\
\text { modern. }\end{array}$ \\
\hline 8. & Pengecatan & $\begin{array}{l}\text { Seluruh mobil menggunakan cat } \\
\text { profesional komputer kelas mobil, cat, } \\
\text { peralatan penyemprotan. }\end{array}$ \\
\hline 9. & Ban & Roda Paduan Khusus Golf, Vacuum Tire. \\
\hline 10. & Frame & $\begin{array}{l}\text { Rangka Hollow } 3 \times 3 \text { dengan cat tahan karat } \\
\text { dengan perpaduan besi } U \text {. Menggunakan } \\
\text { sistem rangka tangga yang lebih kuat, } \\
\text { rigid, dan ringan. }\end{array}$ \\
\hline 11. & Pengemudian & $\begin{array}{l}\text { Rak reduksi dan pinion tunggal, } \\
\text { Mengadopsi mesin kemudi mobil untuk } \\
\text { menyesuaikan jarak secara otomatis. } \\
\text { Pencocokan mekanisme trapesium yang } \\
\text { sempurna, rotasi tanpa sudut yang mati, } \\
\text { arah lebih ringan. }\end{array}$ \\
\hline 12. & $\begin{array}{l}\text { Suspensi } \\
\text { Depan }\end{array}$ & $\begin{array}{l}\text { As roda depan dan suspensi adalah } \\
\text { suspensi independen dari kejutan hidrolik } \\
\text { Silinder. }\end{array}$ \\
\hline 13. & $\begin{array}{l}\text { Suspensi } \\
\text { Belakang }\end{array}$ & $\begin{array}{l}\text { As roda belakang merupakan poros } \\
\text { belakang tipe integral, awet dan handal. } \\
\text { Suspensi daun pegas belakang, shock } \\
\text { absorber hidrolik silinder bisa } \\
\text { menghasilkan bobot lebih }\end{array}$ \\
\hline 14. & $\begin{array}{l}\text { Sistem } \\
\text { Pencahayaan }\end{array}$ & $\begin{array}{l}2 \text { lampu depan, } 2 \text { sinyal belokan depan, } 2 \\
\text { sinyal belok belakang dan } 2 \text { lampu rem } \\
\text { belakang }\end{array}$ \\
\hline 15. & Dashboard & $\begin{array}{l}\text { Dilengkapi dengan kunci pintu listrik } \\
\text { mewah, meteran listrik }\end{array}$ \\
\hline 16. & Sistem Rem & $\begin{array}{l}\text { Pengoperasian yang sangat sederhana } \\
\text { dengan tingkat keamanan yang tinggi. } \\
\text { Penggunaan sistem hidrolik yang sama } \\
\text { dengan mobil konvensional }\end{array}$ \\
\hline 17. & Solar Cell & $\begin{array}{l}\text { Menggunakan energi dari matahari } \\
\text { semakin membuat mobil listrik ini ramah } \\
\text { lingkungan dan Re-Newable Energy }\end{array}$ \\
\hline
\end{tabular}

Uji coba mobil ini dilakukan langsung oleh Rektor Universitas Lambung Mangkurat dengan rute mengelilingi gedung Auditorium ULM Banjarbaru (Gambar 19).

\section{Kesimpulan}

Untuk menciptakan mobil yang hemat energi dilakukannya berbagai macam riset dan penelitian dengan data yang akurat. Pemilihan material dalam pembuatan unit mobil listrik merupakan hal yang penting, penggunaan material besi hollow untuk chasis 
mempunyai banyak kelebihan diantaranya harganya yang murah, untuk kualitasnya lebih bagus dari besi biasanya, bobot lebih ringan dan mudah diaplikasikan.

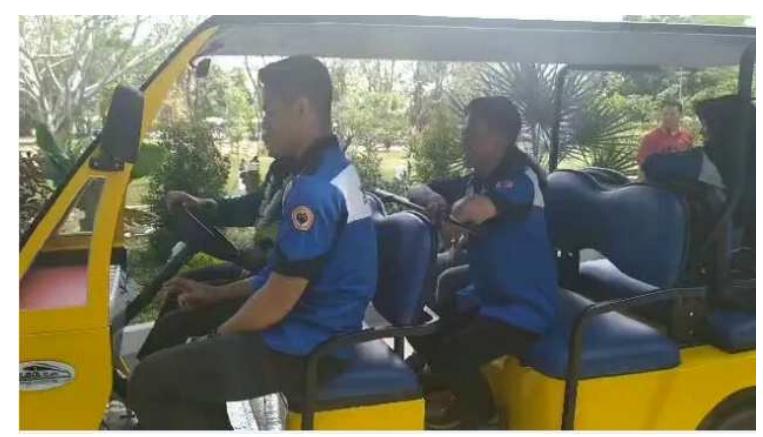

Gambar 19 Uji coba mobil listrik pertama oleh Rektor Universitas Lambung Mangkurat (Prof. Sutarto Hadi)

Penggunaan plat galvanis sebagai body dari mobil listrik juga memiliki berbagai kelebihan, diantaranya mudah untuk dibentuk sesuai dengan desain, prosesnya yang cepat, dan lebih ringan. Dengan bentuknya yang aerodinamis, unit mobil listrik mampu membuat gesekan body dengan angin menjadi lebih kecil, dengan koefisien drag 49,152 N.

Untuk membuat unit mobil listrik memiliki gesekan yang minim adalah dengan mengganti bearing yang ada dengan menggunakan bearing yang minim akan gesekan. Penggunaan sistem penggerak menggunakan gardan dengan perbandingan rasio 1:15 yang diterapkan pada as roda belakang bertujuan untuk mengurangi beban mesin untuk bekerja.

Dengan cara kerja ketika mesin mengalami akselerasi as roda belakang akan berputar bersamaan dengan rodanya, tetapi ketika mesin mengalami disakselerasi as roda akan berhenti berputar, hanya roda saja yang berputar. Sehingga, konsumsi daya akan menjadi lebih hemat dan efisien dikarenakan kerja mesin yang tidak berat. Dengan harapan terciptanya mobil listrik yang ramah lingkungan untuk mewujudkan Universitas Lambung Mangkurat yang berbasis EcoGreen.

\section{Ucapan Terimakasih}

Penulis mengucapkan terima kasih kepada:

Bapak Prof. Dr. H. Sutarto Hadi, M.Si., M.Sc (Rektor Universitas Lambung Mangkurat) yang telah memberi fasilitas dan dukungan dana dalam proyek Mobil Listrik ini.

Bapak Dr. Bani Noor Muchamad, ST., MT. (Dekan Fakultas Teknik Universitas lambung Mangkurat) yang telah memberikan tugas untuk membimbing mahasiswa teknik mesin dalam proyek Mobil listrik ini.

\section{Referensi}

Bambang Setyono, Setyo Gunawan, 2015, Perancangan Dan Analisis Chassis Mobil Listrik "Semut Abang" Menggunakan Software Autodesk Inventor Pro 2013, Seminar Nasional Sains dan Teknologi Terapan III 2015 ISBN 978-602-98569-1-0 Institut Teknologi Adhi Tama Surabaya.

Belingardi, G., Obradovic, J. (2010). Design of the Impact Attenuator for a Formula Student Racing Car: Numerical Simulation of the Impact Crash Test. Journal of the Serbian Society for Computational Mechanics, 4 (1), 52-65.

Lilis Setiono, 2016, PERANCANGAN MEKANIKA DAN REALISASI KONTROL MOBIL LISTRIK, ISSN : 2355-9365 e-Proceeding of Engineering : Vol.3, No.3 December 2016 | Page 4669.

Marlia Adriana, Anggun Angkasa B.P, Masrianor, 2017, Rancang Bangun Rangka (Chasis) Mobil Listrik Roda Tiga Kapasitas Satu Orang, Jurnal Elemen Volume 4 Nomor 2, Desember 2017.

Marzuki, M. A. B., Abu Bakar, M. A., Mohammed Azmi, M. F. (2015). Designing space frame race car chassis structure using natural frequencies data from ansys mode shape analysis. International Journal of Information Systems and Engineering, 3 (1), 54-63. doi:

https://doi.org/10.24924/ijise/2015.11/v3.iss1/54.6 3.

Nugroho, U., Anis, S., Kusumawardani, R., Khoiron, A. M., Maulana, S. S., Irvandi, M., Mashdiq, Z. P. (2018). Frame Analysis of UNNES Electric Bus Chassis Construction Using Finite Element Method. Engineering International Conference (EIC2017) AIP Conf. Proc., 1941, 020017-1-020017-4. doi: https://doi.org/10.1063/1.5028075.

Rudi Siswanto, Rachmat Subagyo, Hajar Isworo, Femiana Gapsari, Modeling Analysis of the Effect of the Main Rollhoop Length on the Strength of Formula Student Chassis, Eastern-European Journal of Enterprise Technologies ISSN 1729-3774 4/7 (100) 2019, DOI: 10.15587/1729-4061.2019.162833.

Reza Arif Syaifulah, Hardhani Eko Kurniawan, Bagus Priyohandoko, 2012, Mobil Listri 'ZEON' (Zero Pollution) Sebagai Sarana Wisata di Ekowisata Manggrove Wonorejo, Politeknik Elektronika Negeri Surabaya.

Taufik, A. Z., Rashid, N., lan, M., Faruq, M., Zahir, M. (2014). Electric car chassis design and analysis by using CATIA V5 R19. IOSR Journal of Mechanical and Civil Engineering, 11 (4), 56-69. doi: https://doi.org/10.9790/1684-11435669.

Wang, H., Tan, K. H., Yang, B., Peng, J. (2017). 15.04: Parametric study on steel beams with fin-plate joints under falling floor impact. Ce/papers, 1 (2-3), 39103919. doi: https://doi.org/10.1002/cepa.447. 